\title{
Improvement of Sensory Quality of Lowfat Kefalograviera-Type Cheese by Using Commercial Special Starter Cultures
}

\author{
M. C. Katsiari, L. P. Voutsinas, and E. Kondyli \\ National Agricultural Research Foundation, \\ Dairy Research Institute, 45221 Katsikas, Ioannina, Greece
}

\begin{abstract}
Two commercially available special starter culture systems, Alp DIP and a mixture of Alp DIP D and Joghurt V1, were compared with one commercial regular starter culture, $\mathrm{CH}-1$, for their effects on the compositional, sensory and textural characteristics of lowfat (9.5\%) high moisture (49.6\%) Kefalograviera-type cheese during aging. A full-fat control Kefalograviera cheese (30.8\% fat, $37.8 \%$ moisture) was also made with the regular starter culture. The results indicated that the type of starter did not affect the composition (moisture, fat, protein, salt and $\mathrm{pH}$ ) of the lowfat cheese. Sensory analysis showed that the lowfat cheeses made with the special cultures received greater body and texture scores and significantly higher flavor scores than the lowfat control cheese after aging for 90 and $180 \mathrm{~d}$. Moreover, the former cheeses received body and texture and flavor scores not significantly different from those of the full-fat cheese. Texture profile analysis by Instron showed that there were no significant differences in the textural characteristics (force and compression to fracture, cohesiveness, springiness, gumminess and chewiness) between lowfat cheeses made with the special cultures and that made with the regular starter, except for hardness which was significantly lower in the former cheeses.
\end{abstract}

(Key words: lowfat cheese, Kefalograviera cheese, starter cultures)

Abbreviation key: FFA = free fatty acids, MNFS = moisture in the non-fat substance, PTA-SN = nitrogen soluble in 5\% phosphotungstic acid, TCA-SN = nitrogen soluble in $12 \%$ trichloroacetic acid, $\mathbf{T N}=$ total nitrogen, WSN $=$ water-soluble nitrogen .

\section{INTRODUCTION}

Dietary fat has been shown to be associated with an increased risk of obesity, atherosclerosis, coronary

Received January 29, 2002.

Accepted June 13, 2002.

Corresponding author: L. P. Voutsinas; e-mail: instgala@otenet.gr. heart disease, elevated blood pressure and tissue injury diseases associated with lipid oxidation (Fenelon and Guinee, 2000). This association has created increased consumer awareness and a dramatic increase in the supply of, and demand for, lowfat foods, including cheese (Dexheimer, 1992). However, the consumption of low/reduced-fat cheeses is still low because of the poor consumer perception of the products, based on inadequate taste and texture (Jameson, 1990; Olson and Johnson, 1990; Muir et al., 1992). Lowfat cheeses have low intensity of typical flavor, bitter taste and hard, rubbery, dry and grainy texture (Ohren and Tuckey, 1969; Emmons et al., 1980). Therefore, the challenge in lowfat cheese developments is to improve both the sensory attributes and texture of the product to produce a cheese that is comparable to its full-fat counterpart (Wilkinson et al., 2001).

Several approaches have been investigated for the potential to improve the flavor and texture of lowfat cheeses, e.g. modification of conventional manufacturing process, use of enzymes, additives (stabilizers and fat replacers), specially designed starters or adjunct cultures (Rodriguez, 1998; Fenelon and Guinne, 2000; Mistry, 2001). Combinations of these approaches have also been studied.

Starter organisms play an important role in cheese manufacture because of their contribution to proteolysis, and hence texture and flavor development (Mistry, 2001). Johnson and Chen (1991) reported that the selection of the proper starter culture is important for all cheeses but especially for lowfat cheeses. These workers observed that starters that normally produce a high quality standard fat Cheddar cheese may not necessarily produce a good quality reduced-fat cheese, and noted that only a few of the starters tested resulted in aged reduced-fat cheeses free of meaty-brothy off-flavors. They also suggested that the slower acid producing starters are more desirable in the production of lowfat cheeses, since the development of acid is a critical parameter in these cheeses. Because reduced- and lowfat cheeses contain more moisture, a slow rate of acid development during the cheesemaking process is essential to maintain a strong buffering capacity in the cheese and prevent intense acid flavors resulting (Drake and 
Swanson, 1995). The use of slower acid producing starters is aimed at the control of acid production. Starters selected for lowfat cheesemaking should be able to undergo autolysis at the low production temperatures and high cheese moisture content (Ardo, 1997). It is also desirable to have starters with low proteolytic but high peptidolytic activities (Mistry, 2001). Many culture houses now provide lactic acid starter cultures that have been specially designed for the manufacture of reduced-and lowfat cheeses. These cultures are characterized by slow growth, slow acid development and low proteolytic activity (Drake and Swanson, 1995; Mistry, 1995).

In a preceding work (Katsiari and Voutsinas, 1994) we found that lowfat Kefalograviera, a popular PDO cheese, of acceptable quality can be made from ewe's milk containing $1.5 \%$ fat by modifying the conventional cheesemaking procedure. However, the cheese was inferior in flavor quality and physical characteristics to the full-fat counterpart made from milk with $6.0 \%$ fat. The objectives of the present study were to extend the work of Katsiari and Voutsinas (1994) in order to improve the sensory quality of lowfat, high moisture Kefalogravieratype cheese using commercial special starter cultures. The effects of the use of different starters on the compositional, sensory and textural characteristics of lowfat Kefalograviera-type cheese during aging are reported in this paper.

\section{MATERIALS AND METHODS}

\section{Starter Cultures}

The commercially available starter cultures used in the cheesemaking of this study were the following:

1. CH-1: a regular (control) thermophilic starter culture consisting of a mixture (1:1) of Streptococcus thermophilus and Lactobacillus delbrueckii subsp. bulgaricus (Chr. Hansen's Laboratorium, Copenhagen, Denmark). This culture is used commercially for the production of full-fat Kefalograviera cheese.

2. Alp DIP: a specially defined multiple-species starter culture consisting of a mixture of Lactococcus lactis subsp. lactis, Lactococcus lactis subsp. cremoris, Streptococcus thermophilus, Lactobacillus helveticus and Lactobacillus lactis. This culture was selected on the basis of preliminary positive results obtained in an initial culture screening for the production of high quality lowfat Kefalograviera-type cheese.

3. Alp DIP D: a special starter culture containing Alp DIP culture and Lactococcus lactis subsp. lactis biovar. diacetylactis. It was used along with Joghurt V1 culture, a thermophilic, undefined multiple- species culture, consisting of $S$. thermophilus and L. delbrueckii subsp. bulgaricus. The selection of Alp DIP D culture was based on the expected good results of Alp DIP culture and on the ability of $L c$. lactis subsp. lactis biovar. diacetylactis to produce acetate, diacetyl and acetoin from citrate fermentation (Midje et al., 2000). Acetate is the dominant free fatty acid (FFA) in full-fat Kefalograviera cheese comprising $34 \%$ of all FFA present in the mature (180-d-old) cheese (Katsiari et al., 2001). The Alp DIP, Alp DIP D and Joghurt V1 cultures were gifts from WIESBY GmbH \& Co. KG (Niebull, Germany).

\section{Cheese Manufacture}

Bulk ewes' milk was obtained from the herd of the Agricultural Research Station of Ioannina and standardized to $6.0 \%$ fat for the full-fat cheese and $1.5 \%$ fat for the lowfat cheeses by mixing skim milk and whole milk. Full-fat and lowfat cheeses were made according to the conventional and modified methods, respectively, of Katsiari and Voutsinas (1994), with the following exceptions: (1) $10 \mathrm{~g}$ of calcium chloride were added per $100 \mathrm{~kg}$ of lowfat cheese milk instead of $27 \mathrm{~g}$ and (2) brine-salting of lowfat cheeses was made by immersion in $18 \%$ (wt/wt) $\mathrm{NaCl}$ solution instead of $20 \%$. Four vats of cheese were made in $1 \mathrm{~d}$. The cheeses were designated as lowfat made with the special culture Alp DIP (cheese A), lowfat made with special culture Alp DIP D supplemented with the culture Joghurt V1 (cheese B), lowfat control made with the regular lactic culture $\mathrm{CH}-1$ (cheese C), and full-fat control made with the latter culture (cheese D). The special cultures were added directly to the cheese milk at the supplier's recommended levels, i.e., the Alp DIP at a rate of 1.0 units/ $100 \mathrm{~L}$, the Alp DIP D at a rate of 0.2 units $/ 100 \mathrm{~L}$, and the Joghurt V1 at a rate of 0.1 units/100 L cheese milk. The ripening period was $10 \mathrm{~min}$. The control culture was grown in $10 \%$ (wt/wt) reconstituted, heat-treated $\left(120^{\circ} \mathrm{C}\right.$ for $\left.15 \mathrm{~min}\right)$ skim milk powder at $43^{\circ} \mathrm{C}$ and was added to the cheese milk at a rate of $0.4 \%$ (wt/wt). The experiment was replicated three times.

Samples were taken from a given cheese at 5, 25, 60,90 and $180 \mathrm{~d}$ after manufacture for assessment of compositional characteristics. The values reported are the means of the three replicate cheesemaking trials.

\section{Chemical Analyses}

Full- and lowfat cheese milks were analyzed for fat and casein as described by Katsiari and Voutsinas (1994). The grated cheese samples were analyzed for fat, protein, moisture, salt, $\mathrm{pH}$, water-soluble nitrogen 
(WSN), nitrogen soluble in $12 \%$ thichloroacetic acid (TCA-SN), and nitrogen soluble in 5\% phosphotungstic acid (PTA-SN) as described by Katsiari and Voutsinas (1994). The concentrations of soluble nitrogen fractions were expressed as percentages of total nitrogen (TN). Total free fatty acids (TFFA) of cheeses were calculated by summing up the individual FFA determined as described by Katsiari et al. (2001).

\section{Sensory Evaluation}

Samples of Kefalograviera cheese were cut into pieces about $3 \times 3 \times 2 \mathrm{~cm}$ in size and placed on white plates coded with three-digit random numbers. The cut samples were tempered by holding at ambient temperature $\left(18 \pm 2^{\circ} \mathrm{C}\right)$ and then presented to the panelists in a random order for testing. Water was provided for mouth washing between samples. The cheeses were evaluated organoleptically after 90 and $180 \mathrm{~d}$ of ripening by a five-member panel from the Institute's staff familiar with Kefalograviera cheese. The panelists had attended a general program (attributes, scale, description of sensory impressions and common cheese defects) on the sensory evaluation of cheese. Moreover, prior to sensory evaluation, the panelists participated in a review session. Panel members evaluated cheese for appearance, body and texture, and flavor (odor and taste) using a 10-point scale, with 1 being the worst and 10 the best quality. Importance was given predominantly to the attributes of flavor and of body and texture over the appearance of the cheese, as advised by the IDF (1987). Thus, the scores obtained for these two attributes were multiplied by 5 and 4 , respectively. The total score was obtained by adding the scores for the three sensory attributes. An excellent cheese received a total score of 100. Panel members were also instructed to report any defects in appearance (e.g., cracks), body and texture (e.g., rubbery, granular, crumbly, hard) or flavor (e.g., acid, rancid, bitter, salty), detected according to the IDF (1987) guide for the sensory evaluation of cheese.

\section{Texture Evaluation}

Compression testing was performed on the cheeses after 90 and $180 \mathrm{~d}$ of ripening using an Instron Universal Testing Instrument, Model 1011 (Instron Ltd., High Wycombe, Bucks, UK), equipped with a 50-kg load cell and a Yokogawa Model 3021 pen recorder. A plunger, 35 $\mathrm{mm}$ in diameter, was attached to the moving crosshead. Cylindrical samples (diameter $14 \mathrm{~mm}$, height $15 \mathrm{~mm}$ ) of each cheese $\left(4^{\circ} \mathrm{C}\right)$ were prepared from 4 -cm-thick slab of cheese, cut at least $30 \mathrm{~mm}$ from the cheese surface, using a cork borer. The long cylindrical samples were cut with a thin-bladed sharp knife to the desired height.
Once the samples were cut, they were placed in airtight plastic boxes and allowed to equilibrate to assay temperature $\left(19 \pm 1^{\circ} \mathrm{C}\right)$. The operating conditions were: crosshead speed $30 \mathrm{~mm} / \mathrm{min}$, chart speed $60 \mathrm{~mm} / \mathrm{min}$ and chart recording range $0-20 \mathrm{~kg}$. From each forcedistance curve, obtained by compression of the sample to $80 \%$ in two bites, the following texture-profile parameters were determined as described by Bourne (1978): (i) the force $(\mathrm{kg})$ required to fracture the cheese sample, i.e., the force recorded at the fracture inflection (yield point), as a measure of fracturability, (ii) the compression (\%) at which the sample fractured, as a measure of cheese shortness, (iii) the compressive force $(\mathrm{kg}) \mathrm{re}-$ corded at maximum compression during the first bite, i.e., the force recorded at $80 \%$ compression of the sample, as a measure of cheese hardness; (iv) the ratio of the positive-force area under the curve during the second compression (bite) to that during the first compression $\left(\mathrm{A}_{2} / \mathrm{A}_{1}\right)$, as a measure of cohesiveness; ( $\mathrm{v}$ ) the height $(\mathrm{mm})$ that the sample recovered during the time that elapsed between the end of the first bite and the start of the second bite, as a measure of springiness (elasticity); (vi) the product of hardness $\times$ cohesiveness (kg), as a measure of gumminess; and (vii) the product of gumminess $\times$ springiness $(\mathrm{kg} \times \mathrm{mm})$, as a measure of chewiness. Five measurements were made for each cheese and the results were averaged. The mean values $\pm \mathrm{SE}$ for the three replicate cheesemaking trials are reported.

\section{Statistical Analysis}

The data were subjected to an analysis of variance using Statgraphics (Statistical Graphics Corp., Rockville, MD). When significant $(P<0.05)$ differences were found among treatments, means were compared using Tukey's test (Steel and Torrie, 1960). Simple linear correlation analysis was used to determine the relationships between the flavor score and the variables reflecting the degree of proteolysis [e.g., WSN (\% TN), TCA-SN (\% TN), PTA-SN (\% TN)] or lipolysis (TFFA). This analysis was carried out using the SPSS program (SPSS Inc., Chicago, USA).

\section{RESULTS AND DISCUSSION}

\section{Compositional Characteristics}

The mean casein: fat ratios of the milks used for the full-fat and lowfat cheeses were 0.82 and 3.34, respectively. The mean values for the compositional characteristics of the full-fat and lowfat cheeses made using the different starter cultures during aging are shown 


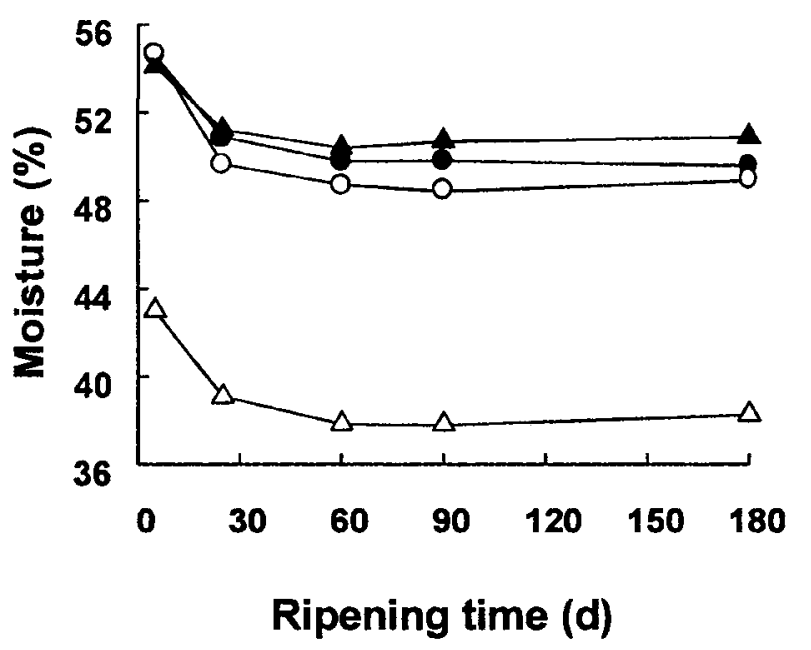

Figure 1. Moisture contents in cheeses during $180 \mathrm{~d}$ of aging. A = lowfat cheese made with starter culture Alp DIP (-), B = lowfat cheese made with starter cultures Alp DIP D and Joghurt V1 (A), $\mathrm{C}=$ lowfat control cheese made with starter culture CH-1 (O), and $\mathrm{D}=$ full-fat control cheese made with starter culture $\mathrm{CH}-1(\triangle)$. Values presented are the means from three replicate trials.

in Figures 1-8. Significant $(P<0.05)$ differences in moisture, fat, fat in dry matter (FDM) and protein were found between full-fat and lowfat cheeses at all sampling ages, while the moisture in the nonfat substance (MNFS), salt, salt in the moisture phase (S/M) and $\mathrm{pH}$ values were similar in all cheeses. The average fat content of the mature (90-d-old) lowfat cheeses was $9.5 \%$, that is $\sim 69 \%$ lower than that of the full-fat cheese $(30.8 \%)$. The gross compositions of the control and ex-

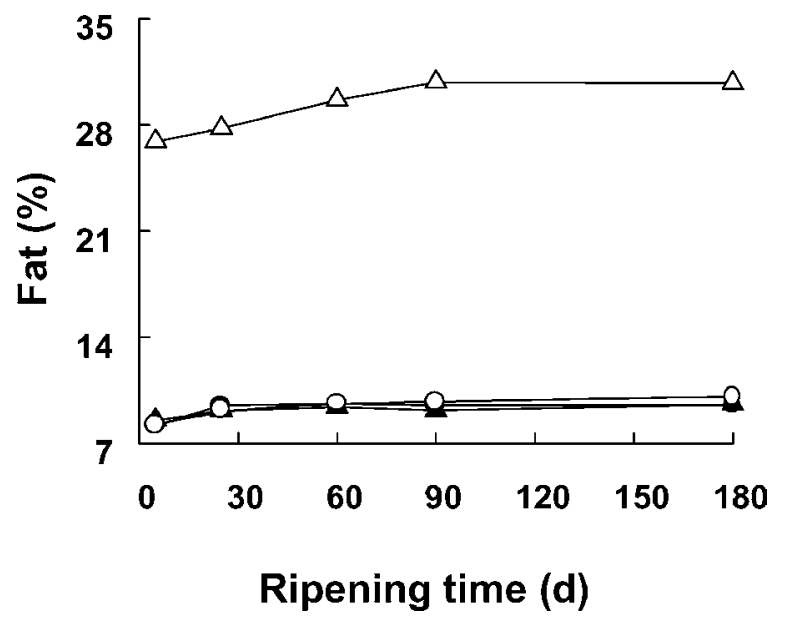

Figure 2. Fat contents in cheeses during $180 \mathrm{~d}$ of aging. A = lowfat cheese made with starter culture Alp DIP $(\bullet), B=$ lowfat cheese made with starter cultures Alp DIP D and Joghurt V1 ( $\mathbf{\Delta}), \mathrm{C}=$ lowfat control cheese made with starter culture $\mathrm{CH}-1(\mathrm{O})$, and $\mathrm{D}=$ full-fat control cheese made with starter culture $\mathrm{CH}-1(\triangle)$. Values presented are the means from three replicate trials.

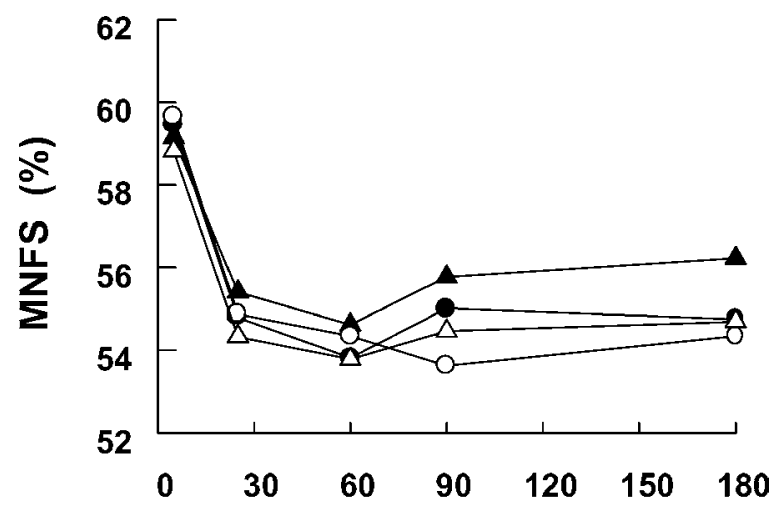

Ripening time (d)

Figure 3. Values of moisture in the non-fat substance (MNFS) in cheeses during $180 \mathrm{~d}$ of aging. A = lowfat cheese made with starter culture Alp DIP $(\bullet), \mathrm{B}=$ lowfat cheese made with starter cultures Alp DIP D and Joghurt V1 ( $\mathbf{\Delta}), \mathrm{C}=$ lowfat control cheese made with starter culture $\mathrm{CH}-1(\mathrm{O})$, and $\mathrm{D}=$ full-fat control cheese made with starter culture CH-1 $(\triangle)$. Values presented are the means from three replicate trials.

perimental lowfat cheeses were similar $(P>0.05)$ throughout aging, indicating that the type of starter culture did not affect the composition of the cheeses. These results are in agreement with those reported for different lowfat cheese varieties by other investigators (Rodriguez et al., 1996; Fenelon et al., 1999), who noted that the composition of reduced-fat cheeses was not affected by the different starter culture systems used in the cheesemaking. On the other hand, Amer et al.

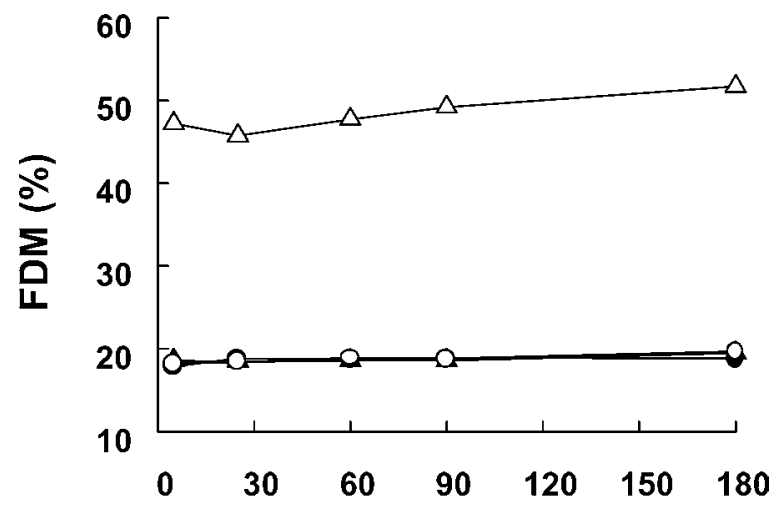

Ripening time (d)

Figure 4. Values of fat in dry matter (FDM) in cheeses during $180 \mathrm{~d}$ of aging. A = lowfat cheese made with starter culture Alp DIP (-), B = lowfat cheese made with starter cultures Alp DIP D and Joghurt V1 (A), C = lowfat control cheese made with starter culture $\mathrm{CH}-1(\mathrm{O})$, and $\mathrm{D}=$ full-fat control cheese made with starter culture CH-1 $(\triangle)$. Values presented are the means from three replicate trials. 


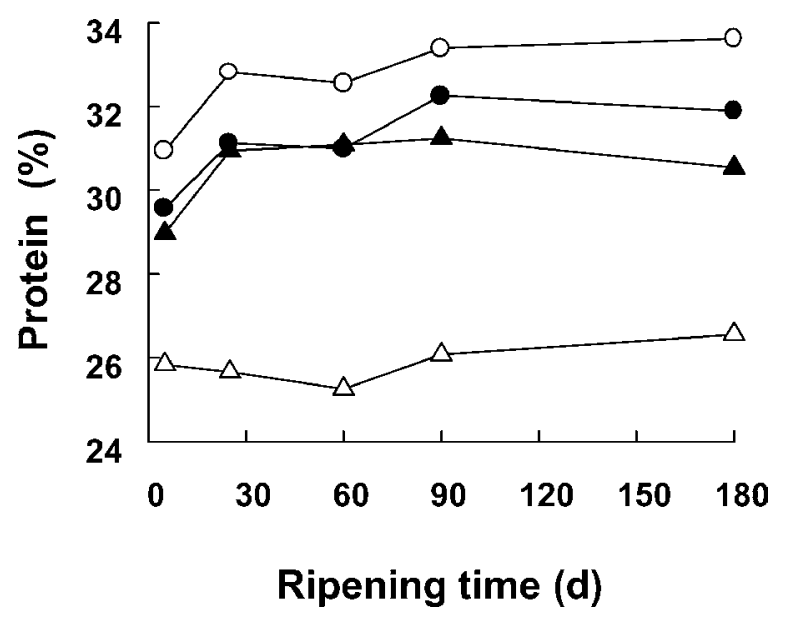

Figure 5. Protein contents in cheeses during $180 \mathrm{~d}$ of aging. $\mathrm{A}=$ lowfat cheese made with starter culture Alp DIP $(\bullet), B=$ lowfat cheese made with starter cultures Alp DIP CD and Joghurt V1 (A), $\mathrm{C}=$ lowfat control cheese made with starter culture $\mathrm{CH}-1(\mathrm{O})$, and $\mathrm{D}=$ full-fat control cheese made with starter culture $\mathrm{CH}-1(\triangle)$. Values presented are the means from three replicate trials.

(1983) studied the effect of the type of starter culture on the properties of lowfat Baby Edam cheese during ripening and found that the type of starter had a marked effect on moisture content and titratable acidity in the cheeses.

\section{Sensory Characteristics}

The results of the sensory panel's assessment of cheese quality at the age of 90 and $180 \mathrm{~d}$ are given in

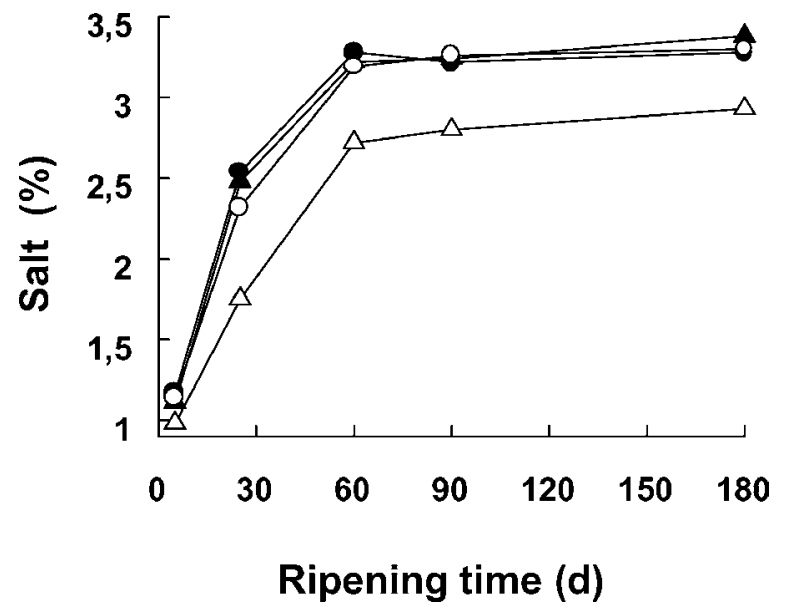

Figure 6. Salt contents in cheeses during $180 \mathrm{~d}$ of aging. $\mathrm{A}=$ lowfat cheese made with starter culture Alp DIP $(\mathbf{\bullet}), \mathrm{B}=$ lowfat cheese made with starter cultures Alp DIP D and Joghurt V1 (A), $\mathrm{C}=$ lowfat control cheese made with starter culture $\mathrm{CH}-1(\mathrm{O})$, and $\mathrm{D}=$ full-fat control cheese made with starter culture $\mathrm{CH}-1(\triangle)$. Values presented are the means from three replicate trials.

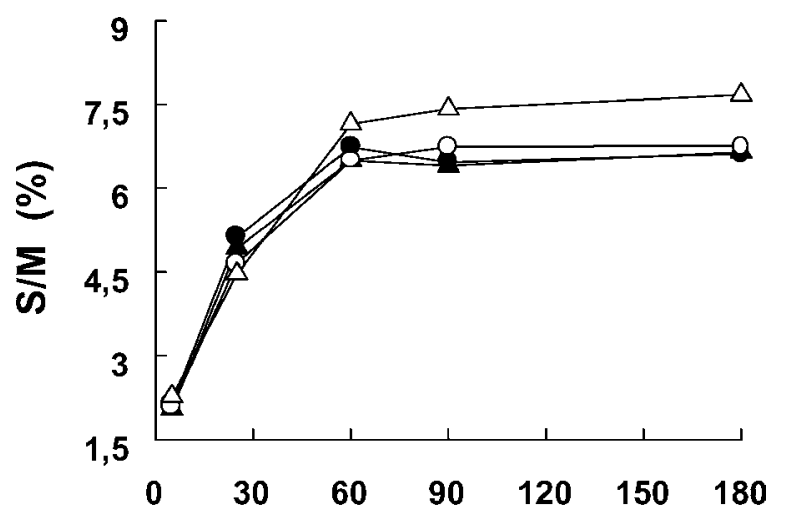

Ripening time (d)

Figure 7. Values of salt in the moisture phase (S/M) in cheeses during $180 \mathrm{~d}$ of aging. $\mathrm{A}=$ lowfat cheese made with starter culture Alp DIP ( ), B = lowfat cheese made with starter cultures Alp DIP $\mathrm{D}$ and Joghurt V1 $(\boldsymbol{\Delta}), \mathrm{C}=$ lowfat control cheese made with starter culture $\mathrm{CH}-1(\mathrm{O})$, and $\mathrm{D}=$ full-fat control cheese made with starter culture CH-1 $(\triangle)$. Values presented are the means from three replicate trials.

Table 1. The appearance of the experimental lowfat cheeses made with the special cultures was considered good at both sampling ages and it was similar $(P>$ 0.05 ) to that of the full-fat control cheese. The body and texture score of the lowfat control cheese made with the regular starter was significantly $(P<0.05)$ lower than that of the full-fat control cheese at both ages (Table 1). This finding may be attributed to the lower level of proteolysis in the former cheese as evidenced

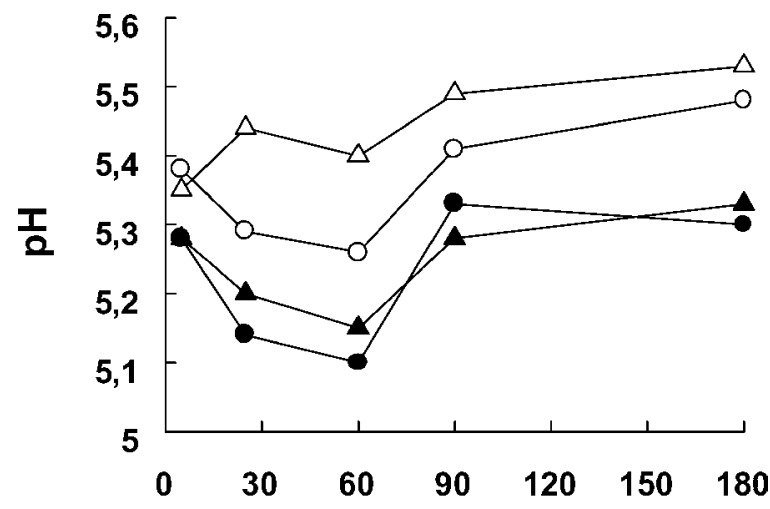

\section{Ripening time (d)}

Figure 8. Cheese $\mathrm{pH}$ during $180 \mathrm{~d}$ of aging. $\mathrm{A}=$ lowfat cheese made with starter culture Alp DIP $(\bullet), \mathrm{B}=$ lowfat cheese made with starter cultures Alp DIP D and Joghurt V1 ( $)$, C = lowfat control cheese made with starter culture $\mathrm{CH}-1(\mathrm{O})$, and $\mathrm{D}=$ full-fat control cheese made with starter culture CH-1 $(\triangle)$. Values presented are the means from three replicate trials. 
Table 1. Sensory characteristics ${ }^{1}$ of full-fat Kefalograviera and lowfat Kefalograviera-type cheeses made using different starter cultures during aging.

\begin{tabular}{llrrrr}
\hline & & \multicolumn{3}{c}{ Cheese } \\
\cline { 3 - 6 } Age of cheese(d) & Sensory characteristic & \multicolumn{1}{c}{$\mathrm{A}^{2}$} & \multicolumn{1}{c}{$\mathrm{C}^{4}$} & \multicolumn{1}{c}{$\mathrm{D}^{5}$} \\
\hline 90 & Appearance $(10)^{6}$ & $8.24 \pm 0.37^{\mathrm{ab}}$ & $8.11 \pm 0.21^{\mathrm{ab}}$ & $7.38 \pm 0.25^{\mathrm{b}}$ & $8.65 \pm 0.05^{\mathrm{a}}$ \\
180 & & $8.33 \pm 0.24^{\mathrm{a}}$ & $8.13 \pm 0.12^{\mathrm{ab}}$ & $7.60 \pm 0.06^{\mathrm{b}}$ & $8.60 \pm 0.15^{\mathrm{a}}$ \\
90 & Body and texture (40) & $32.24 \pm 0.02^{\mathrm{ab}}$ & $31.66 \pm 0.69^{\mathrm{ab}}$ & $29.72 \pm 1.57^{\mathrm{b}}$ & $34.86 \pm 1.14^{\mathrm{a}}$ \\
180 & & $31.90 \pm 0.06^{\mathrm{ab}}$ & $31.93 \pm 0.71^{\mathrm{ab}}$ & $29.18 \pm 0.54^{\mathrm{b}}$ & $34.55 \pm 0.79^{\mathrm{a}}$ \\
90 & & $41.11 \pm 1.04^{\mathrm{a}}$ & $40.51 \pm 0.57^{\mathrm{a}}$ & $31.80 \pm 0.53^{\mathrm{b}}$ & $40.91 \pm 0.45^{\mathrm{a}}$ \\
180 & Flavor (50) & $40.55 \pm 0.07^{\mathrm{a}}$ & $39.14 \pm 1.21^{\mathrm{a}}$ & $31.72 \pm 0.68^{\mathrm{b}}$ & $41.61 \pm 0.29^{\mathrm{a}}$ \\
90 & & $81.59 \pm 1.39^{\mathrm{a}}$ & $80.29 \pm 1.05^{\mathrm{a}}$ & $68.90 \pm 1.97^{\mathrm{b}}$ & $84.42 \pm 1.12^{\mathrm{a}}$ \\
180 & Total $(100)^{6}$ & $80.78 \pm 0.23^{\mathrm{ab}}$ & $79.20 \pm 1.96^{\mathrm{b}}$ & $68.50 \pm 0.55^{\mathrm{c}}$ & $84.77 \pm 0.77^{\mathrm{a}}$ \\
\hline
\end{tabular}

a,b,c Means within row with no common superscript differ $(P<0.05)$.

${ }^{1}$ Mean values and standard error $( \pm$ S.E. $)$ from three replicate trials.

${ }^{2}$ Lowfat made with starter culture Alp DIP.

${ }^{3}$ Lowfat made with starter cultures Alp DIP D and Joghurt V1.

${ }^{4}$ Lowfat control made with starter culture $\mathrm{CH}-1$.

${ }^{5}$ Full-fat control made with starter culture $\mathrm{CH}-1$.

${ }^{6}$ Values in parentheses are maximum attainable scores.

by the lower levels of soluble nitrogen fractions (Table 2). The panelist's comments indicated that the lowfat control cheese had a rubbery, dry and hard body and texture. The use of the special cultures improved the body and texture of the experimental lowfat cheeses over the control counterpart at both 90 and $180 \mathrm{~d}$. Thus, both experimental cheeses were much less rubbery and softer than the lowfat control cheese. These results could be due to the higher proteolysis levels (WSN, TCA-SN, and PTA-SN) in both lowfat cheeses made with the special cultures compared to the lowfat control cheese (Table 2). Enhanced breakdown of the casein matrix, especially $\alpha_{\mathrm{s} 1}$-casein, has been associated with improved texture and smooth body in reduced/lowfat cheeses (Creamer and Olson, 1982; Ardo, 1997). Table 1 also shows that the experimental lowfat cheeses received body and texture scores that were not significantly $(P>0.05)$ different from those of the full-fat cheese at both sampling ages.

Table 1 indicates that the full-fat cheese received from the panelists significantly $(P<0.05)$ higher flavor scores than the lowfat control cheese at 90 and $180 \mathrm{~d}$. These results could be attributed to the higher levels of WSN but mainly to the significantly $(P<0.05)$ higher

Table 2. Proteolysis and lipolysis data ${ }^{1}$ of full-fat Kefalograviera and lowfat Kefalograviera-type cheeses made using different starter cultures during aging.

\begin{tabular}{|c|c|c|c|c|c|}
\hline \multirow[b]{2}{*}{ Age of cheese(d) } & \multirow[b]{2}{*}{ Parameter } & \multicolumn{4}{|c|}{ Cheese } \\
\hline & & $\mathrm{A}^{2}$ & $\mathrm{~B}^{3}$ & $\mathrm{C}^{4}$ & $\mathrm{D}^{5}$ \\
\hline 90 & $\mathrm{WSN}^{6}(\% \mathrm{TN})$ & $21.37^{\mathrm{b}}$ & $21.45^{\mathrm{b}}$ & $18.00^{\mathrm{a}}$ & $19.85^{\mathrm{ab}}$ \\
\hline 180 & & $24.89^{\mathrm{b}}$ & $25.18^{\mathrm{b}}$ & $20.34^{\mathrm{a}}$ & $23.56^{\mathrm{ab}}$ \\
\hline 90 & TCA-SN ${ }^{7}(\% \mathrm{TN})$ & $11.13^{\mathrm{a}}$ & $11.22^{\mathrm{a}}$ & $10.17^{\mathrm{a}}$ & $11.06^{\mathrm{a}}$ \\
\hline 180 & & $13.68^{\mathrm{a}}$ & $14.37^{\mathrm{a}}$ & $12.26^{\mathrm{a}}$ & $14.23^{\mathrm{a}}$ \\
\hline 90 & $\mathrm{PTA}^{\mathrm{PTN}}{ }^{8}(\% \mathrm{TN})$ & $4.72^{\mathrm{ab}}$ & $4.77^{\mathrm{ab}}$ & $3.70^{\mathrm{a}}$ & $5.95^{\mathrm{b}}$ \\
\hline 180 & & $5.06^{\mathrm{ab}}$ & $5.38^{\mathrm{ab}}$ & $4.53^{\mathrm{a}}$ & $6.43^{\mathrm{b}}$ \\
\hline 90 & $\mathrm{TFFA}^{9}(\mathrm{mg} / 100 \mathrm{~g})$ & $64.26^{\mathrm{a}}$ & $72.18^{\mathrm{a}}$ & $62.77^{\mathrm{a}}$ & $105.00^{\mathrm{b}}$ \\
\hline 180 & & $91.67^{\mathrm{a}}$ & $85.05^{\mathrm{a}}$ & $72.61^{\mathrm{a}}$ & $129.75^{b}$ \\
\hline
\end{tabular}

${ }^{\mathrm{a}, \mathrm{b}}$ Means within row with no common superscript differ $(P<0.05)$.

${ }^{1}$ Mean values from three replicate trials.

${ }^{2}$ Lowfat made with starter culture Alp DIP.

${ }^{3}$ Lowfat made with starter cultures Alp DIP D and Joghurt V1.

${ }^{4}$ Lowfat control made with starter culture $\mathrm{CH}-1$.

${ }^{5}$ Full-fat control made with starter culture CH-1.

${ }^{6} \mathrm{WSN}=$ Water soluble nitrogen.

${ }^{7}$ TCA-SN $=$ Nitrogen soluble in $12 \%$ trichloroacetic acid.

${ }^{8}$ PTA-SN $=$ Nitrogen soluble in $5 \%$ phosphotungstic acid.

${ }^{9} \mathrm{TFFA}=$ Total free fatty acids. 


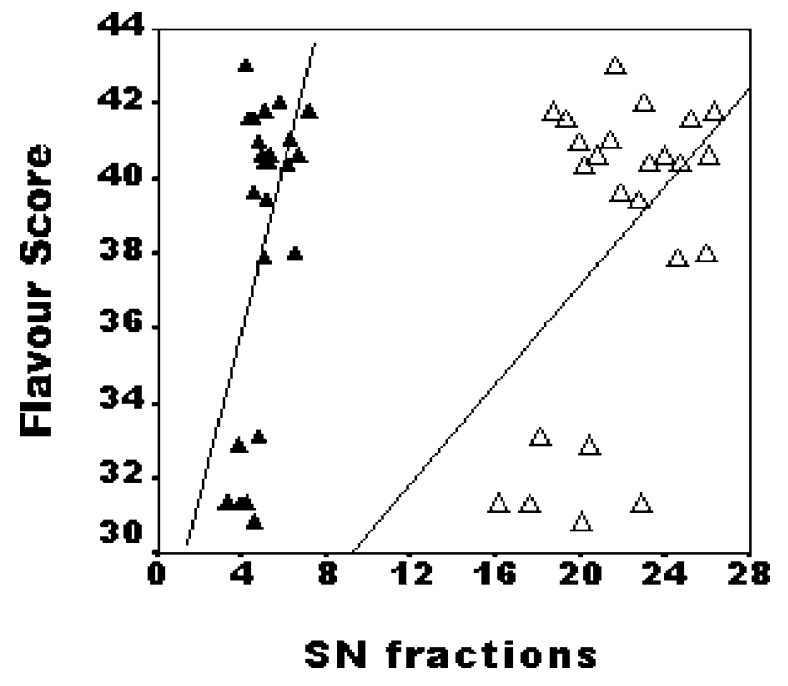

Figure 9. Relationships between flavor score and soluble nitrogen fractions (WSN, $\triangle$; PTA-SN, $\boldsymbol{\Delta}$ ) of cheeses.

concentrations of PTA-SN (small peptides and free amino acids) and total FFA observed in the full-fat cheese compared with the lowfat control cheese (Table 2). This claim is based on correlation analysis, which showed significant positive relationships between flavor score and WSN $(\mathrm{r}=0.459, P<0.05)$ or PTA-SN (r $=0.526, P<0.01)$ of all cheese samples. This correlation can be seen in Figure 9. Moreover, significant positive correlation was found between flavor score and TFFA ( $\mathrm{r}=0.496, P<0.05)$. No significant correlation was found, however, between flavor score and TCA-SN ( $\mathrm{r}=$ $0.230, P>0.05$ ). It should be noted that no significant relationships were found between flavor score and proteolysis or lipolysis indices when the data were analyzed for each cheese separately, most likely due to the small number of cheese samples tested.

The use of the special cultures significantly $(P<0.05)$ improved the flavor intensity of the experimental lowfat cheeses over the corresponding lowfat control cheese at both 90 and $180 \mathrm{~d}$. This finding may be attributed to the higher concentrations of soluble nitrogen fractions (WSN and PTA-SN) and total FFA found in the experimental cheeses than in the lowfat control cheese (Table 2 ). Both experimental lowfat cheeses had flavor scores not significantly $(P>0.05)$ different from those of the full-fat cheese at 90 and $180 \mathrm{~d}$ (Table 2). The lowfat control cheese always exhibited a slight bitterness at both sampling ages, a common defect in aged lowfat cheeses which can be partly explained by the high moisture content (Mistry, 2001). This cheese was also criticized for being flat.

The total score (total assessment) of lowfat Kefalograviera type-cheese was significantly $(P<0.05)$ affected by the type of the starter culture at both sampling ages (Table 1). Both experimental lowfat cheeses received significantly $(P<0.05)$ higher scores for total assessment than the corresponding control cheese. Moreover, there was no significant $(P>0.05)$ difference in total assessment between the lowfat cheese made with the Alp DIP culture and the full-fat control cheese at 90 and $180 \mathrm{~d}$. However, the total score of the lowfat cheese made with a mixture of the Alp DIP D and Joghurt V1 cultures was significantly $(P<0.05)$ lower than that of the full-fat cheese at $180 \mathrm{~d}$.

The positive results of the present study are in agreement with those of other workers who also used different starter cultures to improve the sensory quality of various reduced- and lowfat cheese varieties. Hargrove et al. (1967) found that the type of starter had a marked effect on the flavor and to a lesser degree on the body of a new type of ripened lowfat cheese. Starters containing large proportions of either Leuconostoc or Lc. diacetylactis did not improve cheese quality. $L c$. cremoris starters containing Leuconostoc consistently produced good cheese, whereas cheeses made with starters containing Lc. lactis or Lc. diacetylactis were scored down for acidity or bitterness. Amer et al. (1983) reported that the use of selected mixed starter cultures (Lc. lactis mixed with Lc. cremoris, Lc. lactis subsp. diacetylactis, $L$. casei or $L$. helveticus) improved the organoleptic properties of lowfat Baby Edam cheese over the corresponding control cheese made only with Lc. lactis as starter, giving a strong flavor, slightly acid taste, firm consistency and no abnormal flavors. Olson (1984) found that the type of starter culture had a significant effect on the flavor of Colby-type lowfat cheese. A culture with less proteolytic activity produced a better cheese, with less bitterness and brothiness, than did a more proteolytic culture. Moreover, Fenelon and Guinee (1997) reported that preliminary investigations have shown that the use of a commercially-available starter culture (RFC 300, from Chr. Hansen's Laboratories), in conjunction with an in-house make-procedure, had no effect on grading scores at 3 mo but gave a superior grading score at $6 \mathrm{mo}$. This culture contains 4 strains of Lc. lactis subsp. cremoris selected on the basis of producing good quality, non-bitter standard Cheddar. Finally, Rodriguez et al. (1996) investigated the use of a selected starter culture (IFPL), consisting of several strains of Lactococcus, Lactobacillus and Leuconostoc, to improve the flavor and aroma in a reducedfat semi-hard cheese. The cheeses made with the IFPL starter were awarded the best final scores on both aroma and flavor. At 60 and $90 \mathrm{~d}$ of ripening, the tasting panel found flavor stronger in cheeses made with the selected IFPL starter than in those made with a commercial starter (Flora Danica, from Chr. Hansen, Den- 
Table 3. Textural characteristics ${ }^{1}$ of full-fat Kefalograviera and lowfat Kefalograviera-type cheeses made using different starter cultures during aging.

\begin{tabular}{llrrrr}
\hline & & \multicolumn{3}{c}{ Cheese } \\
\cline { 3 - 6 } Age of cheese(d) & Textural characteristic & \multicolumn{1}{c}{$\mathrm{A}^{2}$} & \multicolumn{1}{c}{$\mathrm{C}^{4}$} & \multicolumn{1}{c}{$\mathrm{D}^{5}$} \\
\hline 90 & Force to fracture (kg) & $4.06 \pm 0.01^{\mathrm{a}}$ & $3.94 \pm 0.22^{\mathrm{a}}$ & $4.26 \pm 0.14^{\mathrm{a}}$ & $3.05 \pm 0.11^{\mathrm{b}}$ \\
180 & & $3.78 \pm 0.38^{\mathrm{a}}$ & $3.68 \pm 0.13^{\mathrm{a}}$ & $4.07 \pm 0.96^{\mathrm{a}}$ & $2.57 \pm 0.27^{\mathrm{b}}$ \\
90 & Compression to & $37.37 \pm 2.06^{\mathrm{a}}$ & $36.82 \pm 0.81^{\mathrm{a}}$ & $39.42 \pm 2.26^{\mathrm{a}}$ & $36.26 \pm 1.61^{\mathrm{a}}$ \\
180 & fracture (\%) & $34.18 \pm 2.71^{\mathrm{a}}$ & $32.47 \pm 1.27^{\mathrm{a}}$ & $37.46 \pm 1.73^{\mathrm{a}}$ & $34.52 \pm 1.49^{\mathrm{a}}$ \\
90 & Hardness (kg) & $11.76 \pm 0.39^{\mathrm{b}}$ & $10.80 \pm 0.49^{\mathrm{b}}$ & $13.29 \pm 0.33^{\mathrm{a}}$ & $7.29 \pm 0.07^{\mathrm{c}}$ \\
180 & & $10.29 \pm 0.17^{\mathrm{b}}$ & $9.50 \pm 0.23^{\mathrm{b}}$ & $11.69 \pm 0.15^{\mathrm{a}}$ & $6.43 \pm 0.34^{\mathrm{a}}$ \\
90 & Cohesiveness & $0.19 \pm 0.01^{\mathrm{a}}$ & $0.19 \pm 0.03^{\mathrm{a}}$ & $0.18 \pm 0.02^{\mathrm{a}}$ & $0.18 \pm 0.00^{\mathrm{a}}$ \\
180 & & $0.17 \pm 0.04^{\mathrm{a}}$ & $0.17 \pm 0.01^{\mathrm{a}}$ & $0.18 \pm 0.01^{\mathrm{a}}$ & $0.17 \pm 0.01^{\mathrm{a}}$ \\
90 & Springiness (mm) & $3.99 \pm 0.34^{\mathrm{a}}$ & $3.82 \pm 0.16^{\mathrm{a}}$ & $4.09 \pm 0.41^{\mathrm{a}}$ & $4.35 \pm 0.42^{\mathrm{a}}$ \\
180 & & $3.70 \pm 0.12^{\mathrm{a}}$ & $3.67 \pm 0.17^{\mathrm{a}}$ & $3.74 \pm 0.22^{\mathrm{a}}$ & $3.94 \pm 0.47^{\mathrm{a}}$ \\
90 & Gumminess (kg) & $2.20 \pm 0.18^{\mathrm{ab}}$ & $2.08 \pm 0.23^{\mathrm{ab}}$ & $2.35 \pm 0.32^{\mathrm{a}}$ & $1.28 \pm 0.04^{\mathrm{b}}$ \\
180 & & $1.80 \pm 0.46^{\mathrm{a}}$ & $1.58 \pm 0.03^{\mathrm{a}}$ & $2.14 \pm 0.13^{\mathrm{a}}$ & $1.09 \pm 0.07^{\mathrm{a}}$ \\
90 & & $8.76 \pm 0.92^{\mathrm{a}}$ & $8.00 \pm 1.19^{\mathrm{a}}$ & $9.79 \pm 1.93^{\mathrm{a}}$ & $5.55 \pm 0.38^{\mathrm{a}}$ \\
180 & Chewiness (kgx mm) & $6.73 \pm 1.80^{\mathrm{a}}$ & $5.80 \pm 0.40^{\mathrm{a}}$ & $8.03 \pm 0.90^{\mathrm{a}}$ & $4.27 \pm 0.50^{\mathrm{a}}$ \\
\hline
\end{tabular}

${ }^{\mathrm{a}, \mathrm{b}, \mathrm{c}}$ Means within row with no common superscript differ $(P<0.05)$.

${ }^{1}$ Mean values and standard error $( \pm$ S.E.) from three replicate trials.

${ }^{2}$ Lowfat made with starter culture Alp DIP.

${ }^{3}$ Lowfat made with starter cultures Alp DIP D and Joghurt V1.

${ }^{4}$ Lowfat control made with starter culture $\mathrm{CH}-1$.

${ }^{5}$ Full-fat control made with starter culture $\mathrm{CH}-1$.

mark). On the other hand, Fenelon et al. (1999) evaluated the effect of the use of different starters on the quality of reduced-fat Cheddar cheese with a high MNFS level ( $55 \%)$ and found that the type of starter culture had no significant effect on flavor or texture scores throughout ripening.

\section{Textural Characteristics}

The results of the objective evaluation of cheese texture after 90 and $180 \mathrm{~d}$ aging are given in Table 3 . The full-fat cheese was significantly $(P<0.05)$ more fracturable and softer than the lowfat cheeses at both sampling ages. This finding is in accordance with the results of Katsiari and Voutsinas (1994) who studied the combined effect of fat reduction and moisture increase in Kefalograviera cheese on the textural characteristics of the cheese. Bryant et al. (1995) also found that as fat in Cheddar cheese decreased and moisture increased, hardness increased. As can be seen from Table 3, the lowfat and full-fat cheeses had similar values for the compression required to fracture the samples, the cohesiveness and the springiness. These results are in agreement with those of Katsiari and Voutsinas (1994) for lowfat high moisture Kefalograviera-type cheese, but in contrast to those of Bryant et al. (1995) who reported that as the fat content in Cheddar cheese decreased and moisture increased, the cohesiveness, as determined by Instron, increased. Table 3 also shows that the lowfat control cheese was significantly $(P<$ 0.05 ) gummier than the full-fat cheese at $90 \mathrm{~d}$.
The lowfat cheeses made with the special starter cultures were significantly $(P<0.05)$ softer than the lowfat cheese made with the regular starter at 90 and $180 \mathrm{~d}$ (Table 3), which may be attributed to the greater degree of proteolysis (higher levels of WSN, TCA-SN and PTASN) observed in the former cheeses (Table 2). There were no significant $(P>0.05)$ differences among the lowfat cheeses made with the different starters in the force and compression required to fracture the samples, the cohesiveness, springiness, gumminess and chewiness (Table 3).

The decrease in the values of all textural characteristics of the cheeses with aging (Table 3 ) is in agreement with the results of Katsiari and Voutsinas (1994) for Kefalograviera cheese of various fat and moisture contents, Creamer and Olson (1982) for Cheddar cheese and Tunick et al. (1991) for Mozzarella cheese, and is probably due to the proteolysis of $\alpha_{\mathrm{s} 1}$-casein, mainly by residual coagulant. Moreover, Fenelon et al. (1999) found that the hardness of all reduced-fat Cheddar cheeses made using different starter culture systems decreased during ripening for $240 \mathrm{~d}$.

\section{CONCLUSION}

The results of this study indicated that the use of the commercially available special starter cultures Alp DIP and Alp DIP D (used along with Joghurt V1 culture) improved the body and texture and highly enhanced the flavor intensity of lowfat high moisture Kefalogravieratype cheese compared with the commercial regular 
starter CH-1. The sensory quality of the lowfat cheeses made with the special starters was not significantly different from that of the full-fat counterpart made with a regular starter. The Alp DIP culture was preferred to the mixture of Alp DIP D and Joghurt V1 cultures, because it gave lowfat cheese with body and texture, flavor and total assessment scores consistently closer to those of the full-fat cheese at both 90 and $180 \mathrm{~d}$.

\section{ACKNOWLEDGMENTS}

This study was performed as part of NAGREF Project No VI/7 in the framework of the Program DEMETRA '95 funded by the National Agricultural Research Foundation of Greece. We thank E. Vassila for technical assistance, A. Velivassis for his valuable help in cheesemaking, and S. Koutelida for typing the manuscript.

\section{REFERENCES}

Amer, S. N., L. A. El-Koussy, E. S. Girgis, and S. M. Ewais. 1983. Effect of the type of starter culture on the properties of lowfat Baby Edam cheese during ripening. I. Some chemical, microbiological and organoleptic properties. Egypt. J. Food Sci. 11:39-44.

Ardo, Y. 1997. Flavor and texture in lowfat cheese. Pages 207-218 in Microbiology and Biochemistry of Cheese and Fermented Milk. B. A. Law, ed. 2nd ed. Chapman \& Hall, London, United Kingdom.

Bourne, M. C. 1978. Texture profile analysis. Food Technol. 32(7):62-66,72.

Bryant, A., Z. Ustunol, and J. C. Steff. 1995. Texture of Cheddar cheese as influenced by fat reduction. J. Food Sci. 60:12161219,1236

Chen, C. M., A. C. Macedo, M. E. Johnson, and N. F. Olson. 1992. Analysis of four starter cultures in the ripening of reduced-fat Cheddar cheese. J. Dairy Sci. 75(Suppl. 1):103(Abstr.).

Creamer, L. K., and N. F. Olson. 1982. Rheological evaluation of maturing Cheddar cheese. J. Food Sci. 47:631-636,646.

Dexheimer, E. 1992. On the fat track. Dairy Foods 93(5):38-50.

Drake, M. A., and B. G. Swanson. 1995. Reduced- and lowfat cheese technology: A review. Trends Food Sci. Technol. 6:366-369.

Emmons, D. B., M. Kalab, E. Larmond, and R. J. Lowrie. 1980. Milk gel structure. X. Texture and microstructure in Cheddar cheese made from whole milk and from homogenized lowfat milk. J. Texture Stud. 11:15-34.

Fenelon, M. A., and T. P. Guinee. 1997. Reduced-fat Cheddar cheese. Pages 62-72 in Proc. 5th Cheese Symp. T. M. Cogan, P. F. Fox and P. Ross, ed. Teagasc, Dublin.

Fenelon, M. A., and T. P. Guinee. 2000. Flavor development in lowfat cheese. Pages 31-42 in Proc. 6th Moorepark Cheese Symp. T. M. Cogan, ed. Teagasc, Dublin.

Fenelon, M. A., M. P. Ryan, M. C. Rea, T. P. Guinee, R. P. Ross, C. Hill, and D. Harrington. 1999. Elevated temperature ripening of reduced-fat Cheddar made with or without lacticin 3147-producing starter culture. J. Dairy Sci. 82:10-22.

Hargrove, R. E., F. E. McDonough, and R. P. Tittsler. 1967. Factors affecting characteristics, composition, and quality of skim milk cheese. J. Dairy Sci. 50:160-166.

IDF. 1987. Sensory evaluation of dairy products. IDF Standard 99A. International Dairy Federation, Brussels.

Jameson, G. W. 1990. Cheese with less fat. Aust. J. Dairy Technol. 45:93-98.

Johnson, M. E., and C. Chen. 1991. Making quality reduced-fat cheese. Pages 35-36 in Proc. Cheese Res. Technol. Conf., Univ. Wisconsin, Madison.

Johnson, M. E., J. L. Steele, J. Broadbent, and B. C. Weimer. 1998. Manufacture of gouda and flavor development in reduced-fat cheddar cheese. Aust. J. Dairy Technol. 53:67-69.

Katsiari, M. C., and L. P. Voutsinas. 1994. Manufacture of lowfat Kefalograviera cheese. Int. Dairy J. 4:533-553.

Katsiari, M. C., L. P. Voutsinas, E. Alichanidis, and I. G. Roussis. 2001. Lipolysis in reduced sodium Kefalograviera cheese made by partial replacement of $\mathrm{NaCl}$ with $\mathrm{KCl}$. Food Chem. 72:193-197.

McGregor, J. U., and C. H. White 1998. Utilization of bacterial cultures as a means of enhancing the production of flavor in lowfat Cheddar cheese. J. Dairy Sci. 71(Suppl. 1):116 (Abstr.).

Midje, D. L., E. D. Bastian, H. A. Morris, F. B. Martin, T. Bridgeman, and Z. M. Vickers. 2000. Flavor enhancement of reduced-fat Cheddar cheese using an integrated culturing system. J. Agric. Food Chem. 48:1630-1636.

Mistry, V. V. 1995. Improving the sensory characteristics of reducedfat cheese. Pages 371-382 in Chemistry of Structure-Function Relationships in Cheese. E. L. Malin and M. H. Tunick, ed. Plenum Publ. Corp., New York, NY.

Mistry, V. V. 2001. Low fat cheese technology. Int. Dairy J. 11:413-422.

Muir, D. D., J. M. Banks, and E. A. Hunter. 1992. Sensory changes during maturation of fat-reduced Cheddar cheese: Effect of addition of enzymatically active attenuated cultures. Milchwissenschaft 47:218-222.

Ohren, J. A., and S. L. Tuckey. 1969. Relation of flavor development in Cheddar cheese to chemical changes in the fat of cheese. J. Dairy Sci. 52:598-607.

Olson, N. 1984. Making a marketable lowfat cheese. Dairy Record 85(10): 115 .

Olson, N. F., and M. E. Johnson. 1990. Light cheese products: Characteristics and economics. Food Technol. 44(10):93-96.

Rodriguez, J. 1998. Recent advances in the development of lowfat cheeses. Trends Food Sci. Technol. 9:249-254.

Rodriguez, J., T. Requena, H. Goudedranche, J. L. Maubois, and M. Juarez. 1996. Accelerated ripening of reduced fat semi-hard cheese from a mixture of cow's, goat's and ewe's ultrafiltrated milk by using a Lac- Prt- strain of lactococci. Lait 76:513-522.

Steel, R. G. D., and J. H. Torrie. 1960. Principles and Procedures of Statistics with Special Reference to the Biological Science. McGraw-Hill, New York, N.Y.

Tunick, M. H., K. L. Mackey, P. W. Smith, and V. H. Holsinger. 1991. Effects of composition and storage on the texture of Mozzarella cheese. Neth. Milk Dairy J. 45:117-125.

Wilkinson, M. G., H. Meehan, C. Stanton, and C. Cowan. 2001. Marketing cheese with a nutrient content. IDF Bull. 363:39-45. International Dairy Federation, Brussels. 